\title{
PERSONAL BRANDING DAN KEKUASAAN POLITIK DI KABUPATEN LUWU UTARA
}

Nila Sastrawati

Fakultas Syariah dan Hukum Universitas Islam Negeri (UIN) Alauddin Makassar

\begin{abstract}
The Research of Personal Branding and Political Power in Luwu Utara Regency is a descriptive qualitative research that focuses on Brand personality is closely related to the modalities of the contestants in addition to political modalities or political party support. In obtaining research data, interviews related to community responses to personal branding by political contestants. In addition to interviews, document studies especially previous research is helpful in completing the required data.

The results show that political contestants are influenced by modalities in building their brand personality. Such modalities include social modalities, economic modalities, and cultural modalities. Social modalities are related to the intensity of contestant interactions with their constituents. Economic modality is related to ownership. The assumption is established in the community that an established future leader has the opportunity to help the community easily and does not depend on the sponsor. Contestants who build larger networks with sponsors will share power based on the amount of cost or cost incurred. Cultural modalities are related to actions, behavior and educational background.

Public response to personal branding offered by the community can be observed from; first, the intelligence of managing the potential of the region as outlined in the vision and mission of the flagship. Second, communication skills with a humanist approach. Third, the ability to manage the emotional constituents especially for the women.
\end{abstract}

\section{Keywords:}

Personal Branding, Power, Politics

\begin{abstract}
Abstrak
Penelitian Personal Branding dan Kekuasaan Politik di Kabupaten Luwu Utara merupakan penelitian kualitatif deskriptif yang berfokus pada Brand personality sangat terkait dengan modalitas yang dimiliki kontestan selain modalitas politik atau dukungan partai politik. Dalam memperoleh data penelitian, dilakukan wawancara terkait respon masyarakat terhadap personal branding yang dilakukan kontestan
\end{abstract}


politik. Selain wawancara, studi dokumen khususnya penelitian terdahulu sangat membantu dalam melengkapi data yang dibutuhkan. Hasil penelitian menunjukkan bahwa kontestan politik sangat dipengaruhi modalitas dalam membangun brand personalitynya. Modalitas tersebut meliputi modalitas sosial, modalitas ekonomi, dan modalitas kultural. Modalitas sosial terkait dengan intensitas interaksi kontestan dengan konstituennya. Modalitas ekonomi terkait dengan kepemilikan. Asumsi yang terbangun dalam masyarakat bahwa calon pemimpin yang mapan memiliki peluang membantu masyarakat dengan mudah serta tidak menggantungkan kepentingan pada pihak sponsor. Kontestan yang membangun jaringan lebih besar dengan sponsor akan membagi kekuasaan berdasarkan besarnya cost atau biaya yang dikeluarkan. Modalitas kultural terkait dengan tindakan, prilaku dan latar belakang pendidikan.

Respon masyarakat terhadap personal branding yang ditawarkan masyarakat dapat dicermati dari; pertama, kecerdasan mengelola potensi wilayah yang dituangkan dalam visi dan misi unggulan. Kedua, kemampuan komunikasi dengan pendekatan humanis. Ketiga, kemampuan mengelola emosi konstituen khususnya bagi kalangan perempuan.

Kata Kunci:

Personal Branding, Kekuasaan, Politik

\section{A. PENDAHULUAN}

$\mathrm{P}$ olitik merupakan suatu wadah atau suasana mendukung keseimbangan minat dan kebutuhan di satu sisi, namun di sisi lain politik juga menciptakan peluang bagi ambisi pribadi atau pemuasan libido meniti tangga kekuasaan. Politik adalah "seni kemungkinan" (the art of possibilities), apa yang tidak mungkin bisa menjadi mungkin dalam politik. Dalam berpolitik terdapat kampanye, diplomasi, dan negosiasi, dalam konteks inilah dibutuhkan kekuatan seni untuk meyakinkan. Politik diyakini dapat merubah seseorang dari "nothing" menjadi "something", setelah dikemas menjadi menarik di atas panggung politik. Dalam konteks ini konsepsi dramaturgi sering digunakan untuk memperoleh kesan yang baik bagi orang lain di luar diri personal yang kemungkinan berbeda dengan realitas sesungguhnya.

Dunia realitas saat ini adalah dunia dengan entitas-entitas yang saling berhubungan secara sistimatis. Ekonomi, hukum, seni, dan politik menyatu menjadi sarana pemenuhan kebutuhan dan prestise. Libido kekuasaan melebur dalam bentuk "citra", sehingga tidak lagi dapat dibedakan antara realitas dengan citra yang ditampilkan, antara kepentingan sub system lain dengan kepentingan kekuasaan, antara kesejahteraan masyarakat dan mempertahankan kekuasaan politik. Realitas tersebut memotivasi individu-individu untuk menggunakan berbagai macam cara untuk meraih dan mempertahankan kekuasaan politik sebagai sesuatu yang lumrah. 
Proses politik sangat bergantung pada dukungan masyarakat atau konstituen yang tidak hanya bersifat relasi temporal tetapi konstituen yang loyalis. Memastikan loyalitas konstituen bukan suatu hal yang mudah, di tengah intensitas persaingan politik yang tinggi. Untuk memenangkan persaingan tersebut maka dibutuhkan strategi kompetitif khususnya dalam menumbuhkan kepercayaan (trust) politik masyarakat kepada partai politik atau politikus. Salah satu strategi yang dilakukan melalui mengemas potensi yang dimiliki kandidat sehingga mampu menciptakan sebuah respon emosional pada diri orang lain. Pada aspek ini, individu dituntut memiliki personal branding yang kuat.

Personal branding membantu dalam pembentukan persepsi masyarakat serta meningkatkan loyalitas masyarakat terhadap pemiliknya. Dengan mengadopi pola pemasaran ekonomi, brand dalam ruang politik menjadi representasei dari diri sang pencari dan pemilik kekuasaan politik. Membangun brand yang kuat dalam politik sama pentingnya ketika kita membangun sebuah brand yang kuat untuk produk komersial atau jasa komersial lainnya.

Kekuasaan politik Kabupaten Luwu Utara, merupakan wilayah yang menarik untuk dikaji terkait penerapan personal branding dalam kekuasaan politik. Sebagai daerah yang mengalami kemajuan yang cukup pesat, dengan ciri masyarakat yang heterogen diasumsikan turut memengaruhi persepsi masyarakat dalam berbagai aspek termasuk politik. Obyek penelitian dibatasi pada jabatan politik yaitu pada jabatan kepala daerah. Fokus penelitian pada jabatan politik dengan asumsi bahwa jabatan politik sangat bergantung pada suara masyarakat sebagai obyek dan subyek politik. Brand merupakan penamaan, istilah, tanda, simbol atau desain, atau sebuah kombinasi diantaranya, yang berfungsi sebagai pembeda suatu produksi dengan yang lain dalam sebuah persaingan. Brand yang dimaksudkan dalam peulisan ini mengarah pada brand dalam relasi sosial, dan tidak mengarah pada pemahaman brand dalam konteks produksi ekonomi. Brand dalam konteks politik mengarah pada kemampuan personal yang dikemas sehingga memiliki nilai dan kualitas. Kemampuan dalam mengemas kualitas pribadi seseorang sehingga orang lain terkesan yang kemudian diletakkan sebagai personal branding. Atas dasar pemikiran di atas, penelitian ini ingin menjawab dua permasalahan pokok yakni; bagaimana bentuk personal branding yang digunakan dalam jabatan politik. Bagaimana respon masyarakat terhadap kesesuaian personal branding dengan kinerja dalam jabatan politik

Brand merupakan penamaan, istilah, tanda, simbol atau desain, atau sebuah kombinasi diantaranya, yang berfungsi sebagai pembeda suatu produksi dengan yang lain dalam sebuah persaingan. Brand yang dimaksudkan dalam penelitian mengarah pada brand dalam relasi sosial, dan tidak mengarah pada pemahaman brand dalam konteks produksi ekonomi. Brand dalam konteks politik mengarah pada kemampuan personal yang dikemas sehingga memiliki nilai dan kualitas. Kemampuan dalam mengemas kualitas pribadi seseorang sehingga orang lain terkesan yang kemudian diletakkan sebagai personal branding. 


\section{B. KERANGKA TEORITIK}

Mengkaji personal branding dalam kajian kekuasaan politik, tidak terlepas dari relevansi teori yang mendasari.

\section{Image (Citra)}

Abad informasi saat ini disebut juga sebagai abad "citraan" (the age of the image), disebabkan realitas dunia yang dibangun oleh teknologi informasi muthahir disesaki oleh citra-citra dengan beragam perwujudan. Abad citraan adalah abad dimana dunia dikuasai oleh representasi dan yang nyata sesungguhnya adalah yang tampak (termasuk simbol), bukan dibalik symbol. ${ }^{1}$

Politik pencitraan (imagology politic) lahir dari implikasi arus informasi dan keterbukaan sistem politik melalui keterlibatan penuh masyarakat untuk ikut menentukan dan mengawal jalannya pemerintahan. Realitas ini menyebabkan Partai politik berlomba-lomba membangun citra yang baik,meskipun pencitraan tersebut telah melampui realitas yang sesungguhnya ${ }^{2}$.

Penggunaan "pencitraan" sebagai salah satu cara melanggengkan kekuasaan berbanding lurus dengan mekanisme hasrat sebagai mesin penggeraknya. Hasrat yang membentuk, menata, dibentuk berdasarkan kemauan dan keinginan sang pembangun citra. Demikian halnya dengan pencitraan yang dibangun sebuah Partai Politik dengan berdasarkan pada mesin politik yang dimiliki, hasrat kekuasaan merupakan agenda penting yang harus terwujud.

Politik pencitraan telah menembus ruang-ruang yang telah diciptakan dengan kondisi awal sebagai ruang netral bagi aktifitas sosial masyarakat dan terbebas dari aspek politik. Ruang-ruang yang bebas dari pretensi dan kepentingan-kepentingan individu maupun sekelompok orang selain kepentingan pemenuhan kepentingan lahiriah dan batiniah sebagai makhluk sosial. Dalam konteks ini, pandangan Easton bahwa politik adalah kekuatan maha dasyat dapat dimaklumi.

Pencitraan politik juga dapat dicermati dari realitas demokrasi sebagai pilar dari sistem politik yang banyak dianut Negara-negara di dunia termasuk di Indonesia. Piliang memandang demokrasi pada dua aspek yakni demokrasi sebagai realitas kehidupan sosial sehari-hari, dan demokrasi sebagaimana ia direpresentasikan sebagai citra (image) di dalam berbagai media informasi. Di satu pihak ada realita demokrasi, dipihak lain terdapat citra demokrasi (image of democracy). Ketika realita demokrasi berjalan secara mutual dengan citra demokrasi, maka akan terbentuk demokrasi sempurna. Sebaliknya ketika citra demokrasi tidak sesuai dengan realita demokrasi maka akan terbentuk demokrasi tak sempurna.

1 Piliang, Yasraf Amir, Postrealitas: Realitas Kebudayaan dalam Era Post Metafisika, (Jalasutra, Jakarta,2004) h.452

${ }^{2}$ Pahmi, Politik Pencitraan, (Gaung Persada Press, Jakarta,2010) h.29 


\section{Modalitas ${ }^{3}$ dalam Politik}

Fukuyama mendefenisikan modal sosial sebagai sekumpulan nilai informal dan norma yang menyebar diantara kelompok yang memungkinkan kerjasama terjadi antara mereka. Kerjasama tersebut terjadi anpabila antar anggota kelompok masyarakat tersebut memenuhi apa yang diharapkan antar mereka bahwa lainnya akan bertingkah laku, dapat diandalkan dan memiliki kejujuran. Kemudian mereka akan saling mempercayai satu dengan lain. ${ }^{4}$ Dari pandangan Fukuyama dapat disimpulkan tiga aspek penting dari modal sosial yakni, pertama: adanya Trust atau kepercayaan dalam lingkup yang lebih luas dalam komunitas. Kedua, adanya reciprocity atau kewajiban timbal balik yang tidak pasif. Dan ketiga, adanya collective action atau tindakan kebersamaan yang saling menguntungkan.

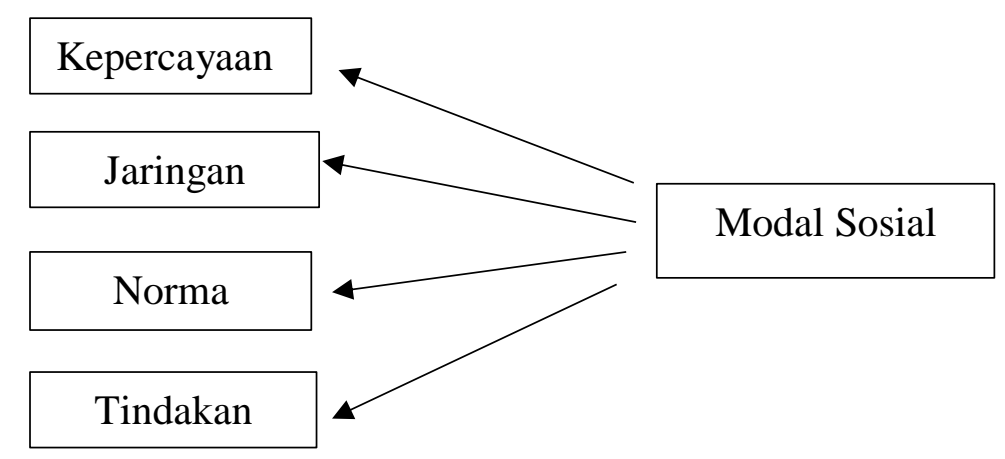

Pandangan Fukiyama mengindikasikan bahwa trust atau kepercayaan berada dalam relasi sosial yang meskipun berawal dalam komunitas itu sendiri, tetapi akan berkembang lebih jauh seiring relasi yang berkembang dan bertransformasi menjadi kekuatan jaringan relasi. Pada perspektif ini, dapat dikatakan bahwa jaringan/relasi merupakan entitas dari kekuasaan politik. Piliang menegaskan bahwa dunia politik tidak diibaratkan sebuah "container" 5 tertutup (istilah yang digunakan Piliang bagi komunitas yang menutup diri dari dunia luar) tetapi dunia yang membutuhkan relasirelasi.

Selain modal sosial, modal finansial merupakan aspek penting dalam kekuasaan politik. Tidak dapat dinafikan bahwa terdapat kecenderungan modal sosial terpinggirkan akibat modal finansial yang mendominasi. Tata Nilai dan norma yang dianut bersama sebagai kearifan local dan menjadi dasar ikatan sosial, tidak menjadi pertimbangan utama ketika persaingan politik berlangsung.

${ }^{3}$ Teori modal dicetuskan pertama kali oleh Piere Bourdieu. Disebutkan bahwa teori ini mempunyai ikatan erat dengan persoalan kekuasaan. Oleh karenanya pemikiran Bourdieu terkonstruk atas persoalan dominasi. Dalammasyarakat politik tentu persoalan dominasi adalah persoalan utama sebagai salah satu bentuk aktualisasi kekuasaan. Pada hakikatnya dominasi dimaksud tergantung atas situasi, sumber daya (kapital) dan strategi pelaku. Lihat, Abd. Halim, Politik Lokal; Pola, Aktor \& Alur Dramatikalnya (Yogyakarta: LP2B, 2014), 108

${ }^{4}$ Rahel Widyawati Kimbal, (Modal Sosial dan Ekonomi Industri: Sebuah Study Kualitatif, Deepublish: Yogyakarta,2015), h.21.

${ }^{5}$ Piliang, Dunia Yang Dilipat: Tamasya Melampaui Batas-Batas Kebudayaan, (Matahari: Bandung 2011) h.191-192 
Kondisi yang menguntungkan akan tercipta baik oleh partai politik maupun kontestan politik jika memiliki modal sosial dan modal capital karena keduanya saling menguat. Ketika politisi dan partai politik memiliki reputasi dan kredibilitas yang tinggi di masyarakat, maka akan lebih mudah mengakumulasi modal capital. Hal ini dapat dilihat ketika partai atau kontestannya membutuhkan suntikan dana dari pendonor, maka pendonor akan memberikan kepada siapapun yang memiliki peluang besar untuk menang. ${ }^{6}$

Persaingan politik yang sangat ketat sangat memungkinkan partai politik dan kontestan yang memiliki modal terbatas akan tersingkir dari kompetisi atau pertarungan politik. Instrumen-instrumen sosialisasi dan kampanye politik yang umum digunakan baik melalui media massa maupun kampanye terbuka membutuhkan dana yang sangat besar.

Modal budaya sangat terkait dengan pemilikan individu terhadap benda-benda material yang dianggap memiliki prestise tinggi, pengetahuan dan ketrampilan yang diakui otoritas resmi dan kebiasaan (gaya pakaian, cara berbicara, selera makan, bahasa tubuh dan sebagainya yang merupakan wujud dari posisi obyektif agen. ${ }^{7}$ Dari pandangan tersebut dapat dikemukakan bahwa latar belakang pendidikan (komitmen terhadap pendidikan), profesi, latar belakang keluarga kelas-kelas sosial merupakan modal budaya.

\section{Teori Tindakan Rasional}

Prinsip dasar teori pilihan rasional berasal dari ekonomi neoklasik. Teori ini menjadi popular ketika Coleman mendirikan jurnal Rationality and Society pada 1989 yang dimaksudkan untuk menyebarkan pemikiran yang berasal dari perspektif pilihan rasional. Teori pilihan rasional menekankan pada tindakan rasional dari individu atau aktor untuk melakukan suatu tindakan berdasarkan tujuan tertentu dan tujuan itu ditentukan oleh nilai atau pilihan (prefensi). Teori pilihan rasional memusatkan perhatian pada aktor. Aktor dipandang sebagai manusia yang mempunyai tujuan atau mempunyai maksud. Artinya aktor mempunyai tujuan dan tindakannya tertuju pada upaya untuk mencapai tujuan itu. Aktor pun dipandang mempunyai pilihan atau nilai, keperluan, yang penting adalah kenyataan bahwa tindakan dilakukan untuk mencapai tujuan yang sesuai dengan tingkatan pilihannya.

\section{Analisis Interaksi: Konsepsi Ervin Goffman}

Usaha untuk mempelajari masyarakat dimulai dengan mengkaji hubungan antara manusia dengan manusia dan hubungan manusia dengan lingkungan luar. Tindakan sosial yang melibatkan sejumlah individu memungkinkan untuk saling memberikan isyarat atau respon, baik dari yang memberi rangsangan maupun penerima dengan penggunaan bahasa. Tindakan tersebut memungkinkan keduanya

\footnotetext{
${ }^{6}$ Firmansyah, Persaingan, Legitimasi Kekuasaan dan Marketing Politik: Pembelajaran Politik Pemilu 2009 (Jakarta: Yayasan Pustaka Obor Indonesia, 2010), h.LVIII

${ }^{7}$ Sofyan Sjaf, Politik Etnik: Dinamika Lokal di Kendari (Yayasan Pustaka Obor, Jakarta 2014) h.70
} 
untuk masuk ke dalam proses berpikir, percakapan antara individu dengan dirinya sendiri untuk menentukan tindakan berikutnya

Individu dituntut untuk mampu memainkan sejumlah peran pada suatu situasi yang berbeda. Disatu sisi, individu akan diperhadapkan pada situasi yang kemungkinan cenderung bertentangan dengan pandangan subyektifnya dan teraktualisasi dalam tindakan-tindakan. Di sisi lain, untuk menarik dukungan politik individu melakukan interaksi intens dengan menggunakan instrumen-instrumen politik (pengaruh dan simbol) dalam percakapan-percakapan tatap muka. Dalam konteks ini, konsep "dramaturgi" Goffman sangat berperan besar dalam menganalisis kemampuan individu memainkan peran, bahasa, dan simbol.

\section{PEMBAHASAN}

Kekuasaan Politik di Kabupaten Luwu Utara tidak terlepas dari dinamika politik dengan intensitas persaingan politik yang cukup tinggi. Sebagai kabupaten yang mengalami perkembangan yang sangat pesat dalam aspek sosial ekonomi, heterogenitas turut memberi kontribusi gerak partisipasi masyarakat termasuk dalam aspek politik. Hal ini dapat dicermati pada pandangan Giddens ${ }^{8}$ bahwa heterogenitas sesungguhnya bukan merupakan halangan, bahkan menjadi bagian penting yang tidak dapat dipisahkan dari makna "cosmopolitan" yang sesungguhnya.

Partisipasi politik masyarakat menjadi bagian penting terciptanya kekuasaan politik antara lain adanya efek simbiosis mutualisma antara kontestan dengan konstituen. Pada posisi ini, dapat dicermati dua pola relasi politik yakni; pertama, konstituen memegang kendali instrument-instrumen (pengaruh dan symbol) yang dibutuhkan konstituen dan harus dipatuhi kontestan. Kedua, kontestan yang telah mendesain instrument-instrumen politik dimana konstutuen hanya pada posisi penyebar atau penerima.

Kedua pola tersebut menunjukkan adanya kesepakatan-kesepakatan pemaknaan terhadap sesuatu yang dimaknai memberi keuntungan politik yang telah disepakati antara kontestan dan konstituen. Konsepsi-konsepsi isu keadilan, kesejahteraan, dan persamaan sebagai isu atau jargon politik baik partai maupun konstituen, pada dasarnya membutuhkan modal politik sehingga isu atau jargon politik dapat sampai ke masyarakat secara maksimal.

Demikian halnya di Kabupaten Luwu Utara. Meskipun penelitian ini tidak memfokuskan pada kekuasaan kepala daerah sebagai jabatan politik tertinggi pada sebuah daerah kabupaten, tetapi pertarungan politik pada ranah ini turut memberi data konstruktif dalam mencermati bentuk dan penerapan personal branding pada daerah tersebut. Hal ini dapat dilihat pada persaingan politik pemilihan Kepala Daerah yang memenangkan bupati perempuan pertama di Sulawesi Selatan.

\footnotetext{
${ }^{8}$ Ketut Arya Mahardika, Jalan Ketiga: Pembaruan Demokrasi Sosial (Jakarta; Gramedia Pustaka, 2000)
} 
Salah satu factor kemenangan Indah Putri Indriani mengalahkan Arifin Junaidi yang merupakan pasangan pejabat daerah periode sebelumnya, adalah kemampuannya mengolah potensi personal atau modal politik yang dimiliki. ${ }^{9}$ Identifikasi modal politik yang digunakan Indah Putri Indriani, berikut ini.

Modal sosial merupakan salah satu modalitas yang dapat dipandang sebagai investasi untuk mendapatkan kepercayaan dari masyarakat. Menjaga keharmonisan dengan masyarakat akan lebih mudah dilakukan bagi seorang pejabat politik dibandingkan masyarakat melalui fasilitas-fasilitas sebagai pejabat politik yang dimiliki. Hal ini sangat disadari Indah Putri Indriani ketika masih menjadi wakil bupati mendampingi Arief Junaidi selaku bupati saat itu. Pemetaan tugas yang dilakukan Arief Junaidi bagi dirinya dengan wakil bupati (Indah Putri Indriani) saat itu justru menjadi keuntungan sendiri bagi wakil bupati. Dari wawancara yang dilakukan, dikemukakan responden bahwa aktifitas sosial kemasyarakatan Indah Putri Indriani sudah sejak lama. Pola komunikasi yang intens pada seluruh lapisan masyarakat dibangun melalui kegiatan-kegiatan sosial, dan terpelihara sampai saat ini.

Pola komunikasi yang dibangun turut memberi kontribusi bertahannya konstituen yang loyalis. Isu-isu yang dibangun berorientasi pada pembangunan ke depan, dan menghindari black campaign terhadap lawan politik. Hal ini berbeda dengan konstestan lain dimana isu gender menjadi substansi utama dalam menjegal lawan politiknya. Akibatnya, konstituen khususnya kaum perempuan justru berbalik arah mendukung Indah Putri Indriani. Ini sangat menentukan apalagi Indah Putri Indriani bukan putri asli daerah Luwu Utara. Indah Putri Indriani membranding dirinya sebagai sosok perempuan cerdas, religious, dengan nilai-nilai kemanusiaan yang elegan. Nilai ini ditunjukkan dengan tanpa sungkan menghadiri undangan masyarakat dari agama yang berbeda.

Komunikasi dibangun pada seluruh elemen masyarakat menjadi modal memperluas jaringan, khususnya dikalangan kelompok-kelompok masyarakat yang tergabung dalam aktifitas sosial kemasyarakatan. Kemampuan mengidentifikasi masalah sebagai hasil komunikasi intens dengan kelompok-kelompok masyarakat dijadikan sebagai isu politik yang dilengkapi dengan argumentasi pemecahan masalah. Pengalaman organisasi yang dimiliki sejak dibangku perkuliahan menjadi modal dalam memperluas jaringan dan dukungan politik masyarakat.

Mencapai jabatan politik bukan hal yang mudah. Seseorang yang memiliki modal sosial belum menjadi jaminan kemenangan politik, jika tidak memiliki ketersediaan dana yang mencukupi. Realita ini mendorong setiap kontestan untuk menyediakan dana baik dana pribadi maupun dari pihak pendukung (sponsor). Hasil wawancara responden dikemukakan, bahwa pada umumnya responden lebih bersimpati pada kontestan yang memang sejak awal memiliki ketersediaan dana

${ }^{9}$ Tawakkal Baharuddin dan Titin Purwaningsih, Modalitas Calon Bupati Dalam Pemilihan Umum Kepala Daerah Tahun 2015, Journal of Governance and Public Policy, Vol 4 No. 1 Februari 2017 
pribadi, dibandingkan kontestan yang diketahui disokong oleh sponsor. Asumsi yang terbangun dalam pikiran responden bahwa keterlibatan berbagai pihak terhadap kontestan tertentu tidak menjamin untuk memberikan dananya kembali setelah kontestan terpilih. Justru sebaliknya, akan menagih hasil sokongan mereka ke kontestan.

Pada kasus jabatan politik di Luwu Utara, latar belakang sosial ekonomi keluarga kontestan turut menjadi perhatian masyarakat. Terlahir dari keluarga yang cukup memadai dalam aspek ekonomi, sokongan dana diperoleh dominan dari keluarga. Profesi sebagai dosen yang berkiprah nasional mengindikasikan bahwa anggaran yang dibutuhkan dapat terpenuhi.

Kemampuan seseorang membangun komunikasi politik yang baik salah satunya dipengaruhi latar belakang pendidikan yang dimiliki dan dijadikan tolak ukur bagi masyarakat untuk memberikan dukungan. Gaya berpakaian, cara bertutur, bahasa tubuh menjadi bagian penting dalam membangun image pada kontestan. Dibandingkan kontestan lain, seorang perempuan yang cerdas, cantik, peduli, keibuan, mampu menjaga keutuhan rumah tangga, akan memperoleh respon positif dari masyarakat.

Modalitas yang dikemas sebagai brand/image figure pada jabatan politik

\begin{tabular}{|c|c|c|}
\hline Modalitas & Unsur-unsur & Brand/image \\
\hline \multirow{3}{*}{ Sosial } & Kepercayaan & Kepeduliaan \\
& Jaringan & Pengalaman \\
& Nilai & Perluasan jaringan \\
& Tindakan & Keberpihakan pada \\
& Kepemilikan Modal & marakat \\
\hline Finansial & Pribadi & $\begin{array}{c}\text { Cerdas } \\
\text { Religius } \\
\text { Budaya }\end{array}$ \\
& Latar belakang keluarga & Cantik \\
\hline
\end{tabular}

Masyarakat memiliki peran besar untuk menentukan figure yang akan menduduki jabatan politik melalui proses demokrasi. Dalam konsepsi demokrasi, pelibatan partisipasi politik masyarakat merupakan suatu keharusan, dan tidak menempatkan masyarakat sebagai obyek semata tetapi sebagai subyek yang turut berkontribusi dalam lajunya pembangunan. Beranjak dari hal tersebut, penelitian ini mengungkapkan respon masyarakat terhadap image yang digunakan dalam personal branding yang diaplikasikan pada jabatan politik.

Hasil wawancara dari responden menunjukkan tiga topologi masyarakat dalam mengenal kontestan (calon) sebagai berikut;

a. Pemilih pemula

Pemilih pemula pada dasarnya sudah mengenal kontestan sebelum menjadi 
pemilih sah melalui kegiatan-kegiatan formal yang mengikutkan lembaga formal, kelompok, organisasi kepemudaan dimana pemilih pemuda menjadi anggotanya. Di samping itu, peran media khususnya media sosial, dan peran tim sukses melalui kegiatan kampanye yang gencar menampilkan image/brand kontestan turut memberi kontribusi dalam menciptakan emosional pemilih untuk berpihak. Tipologi ini cenderung belum intens mengikuti perkembangan program/isu/janji politik, sebelum kontestan terpilih dan lebih focus pada program sarana fasilitas umum khususnya sarana terkait kebutuhannya sebagai pemilih pemula setelah kontestan terpilih.

b. Tim Sukses

Tim sukses merupakan garda terdepan dalam menjembatani kontestan dengan konstituennya. Image/brand yang digunakan kontestan merupakan hasil keterlibatan tim sukses yang mengidentifikasi kebutuhan-kebutuhan masyarakat. Salah satu yang dapat dijadikan acuan adalah, kemampuan tim sukses menganalisis perkembangan Kecamatan Malangke yang giat dalam pembangunan sumber daya manusia melalui pendidikan selain potensi alam. Kontestan melakukan serangkaian kunjungan ke wilayah tersebut, dengan image/brand sebagai figure dengan latar belakang pendidikan akademisi menjadi ukuran bagi masyarakat bahwa kontestan ini merupakan calon pejabat public yang tepat.

c. Masyarakat umum khususnya pemilih perempuan

Permasalahan gender juga menjadi isu politik yang digunakan dalam proses pemilihan jabatan politik di Luwu Utara. Kontestan sangat menyadari bahwa potensi suara perempuan cukup besar (Tindakan Rasional) melalui program pemberdayaan perempuan.

\section{PENUTUP}

Berdasarkan focus penelitian yang dijabarkan dalam dua pertanyaan dasar sebagai rumusan masalah dalam penelitian ini, maka akan dikemukakan kesimpulan dari hasil penelitian sebagai berikut:

1. Brand personality sangat terkait dengan modalitas yang dimiliki kontestan selain modalitas politik atau dukungan partai politik. Modalitas tersebut meliputi modalitas sosial, modalitas ekonomi, dan modalitas kultural. Modalitas sosial terkait dengan intensitas interaksi kontestan dengan konstituennya. Semakin intens interaksi yang terjadi semakin tinggi respon positif dari masyarakat. Modalitas ekonomi terkait dengan kepemilikan. Asumsi yang terbangun dalam masyarakat bahwa calon pemimpin yang mapan memiliki peluang membantu masyarakat dengan mudah serta tidak menggantungkan kepentingan pada pihak sponsor. Kontestan yang membangun jaringan lebih besar dengan sponsor akan membagi kekuasaan berdasarkan besarnya cost atau biaya yang dikeluarkan. Modalitas kultural terkait dengan tindakan, prilaku dan latar belakang pendidikan. Tindakan, prilaku yang baik turut dipengaruhi latar belakang 
pendidikan. Meskipun pendidikan tidak menjadi unsur utama, tetapi asumsi yang terbangun dalam masyarakat bahwa dengan pendidikan yang dimiliki menunjukkan kemampuan seseorang dalam mengkomunikasi sesuatu secara cermat dan tepat.

2. Brand personality yang dijadikan nilai jual politik tidak sepenuhnya menjadi factor utama keberhasilan dalam meraih jabatan politik, jika tidak diiringi dengan realitas sosial. Hal tersebut dapat dilihat dari kekalahan petahana dengan tag line "mannessa" yang dimaknai dengan optimisme untuk menang. Brand personality yang disusun petahana tidak mampu memperoleh dukungan masyarakat untuk duduk pada periode kedua. Pemilahan tugas antara petahana dengan wakilnya, menjadi kemenangan tersendiri bagi wakilnya (Indah Putri) karena interaksi telah dilakukan sebelum dirinya mencalonkan diri sebagai Bupati kabupaten Luwu Utara. Respon masyarakat terhadap personal branding yang ditawarkan masyarakat dapat dicermati dari; pertama, kecerdasan mengelola potensi wilayah yang dituangkan dalam visi dan misi unggulan. Kedua, kemampuan komunikasi dengan pendekatan humanis. Ketiga, kemampuan mengelola emosi konstituen khususnya bagi kalangan perempuan.

\section{Daftar Pustaka}

Ahamdi, Ruslam, Memahami Metode Penelitian Kualitatif, Universitas Negeri

Alwi, Hasan et.al, Kamus Besar Bahasa Indonesia, Balai Pustaka, Bandung, 2003

Baharuddin, Tawakkal dan Titin Purwaningsih, Modalitas Calon Bupati Dalam

Pemilihan Umum Kepala Daerah Tahun 2015, Journal of Governance and Public

Policy, Vol 4 No. 1 Februari 2017.

Baldwin, Jhon D, George Herbert Mead, An Unifying Theory for Sociology, USA: Sage

Budiardjo, Miriam, Partisipasi dan Partai Politik, Yayasan Obor Indonesia, Jakarta, 1998 - Dasar-Dasar Ilmu Politik, PT Gramedia, Jakarta,1986

Bungin, Burhan, Metodologi Penelitian Sosial, Airlangga University Press

Denzin, Norman K, dan Yvonna S Lincoln, 2009, Handbook of Qualitative Research, Pustaka Pelajar, Jogkakarta Denzin, 2000.

Duverger, Maurice, The Study of Politics, diterjemahkan dengan judul Sosiologi Politik,

PT. RadjaGrafindo Persada, Jakarta, 1993.

Eisenring, Tommy, Konstruksi Sosial Arsitektur Atas Konsumtifisme (Studi Interaksionisme

Simbolik pada Tiga Mal Perbelanjaan di Makassar, UNM: disertasi, 2010.

Endarmoko, Eko, Tesaurus Bahasa Indonesia, Gramedia: Jakarta, 2006.

Firmansyah, Mengelola Partai Politik: Komunikasi dan Positioning. , Persaingan, Legitimasi Kekuasaan dan Marketing Politik: Pembelajaran 
Politik Pemilu 2009 (Jakarta: Yayasan Pustaka Obor Indonesia, 2010).

Halim, Abd, Politik Lokal; Pola, Aktor \& Alur Dramatikalnya, Yogyakarta: LP2B, 2014.

Haroen, Dewi, Personal Branding; Kunci Kesuksesan Berkiprah di Dunia Politik, Gramedia, Jakarta, 2014

I Wayan Geriya (balipost.co.id), diakses tanggal 26 Juni 2017.

Jhon, Stephen W Little, Theories of Human Comunication, Belmont; wodsworth Publishing Company, 2009

Kridalksana, Harimurti, Kamus Linguistik, Gramedia; Jakarta, 2008.

Mahardika, Ketut Arya, Jalan Ketiga: Pembaruan Demokrasi Sosial, Jakarta; Gramedia Pustaka, 2000

Mash, Ian, Theory and Practice in Sociology (London, Prentice Hall, Person Education Limited, 2002.

Muhammad, Reza, Kekalahan petahana dalam pilkada 2015 di kabupaten Luwu Utara, Program Studi Ilmu Politik Departemen Ilmu Politik dan Ilmu Pemerintahan Fakultas Ilmu Sosial dan Ilmu Politik Universitas Hasanuddin Makassar, 2017.

Muslih, Mohammad, Filsafat Ilmu, Kajian atas Asumsi Dasar Paradigma dan Kerangka Teori Ilmu Pengetahuan, Yogyakarta: Belukar. 2005.

Pahmi, Politik Pencitraan, Gaung Persada Press, Jakarta, 2010

Piliang, Yasraf Amir, Dunia Yang Dilipat: Tamasya Melampaui Batas-Batas Kebudayaan, Matahari: Bandung 2011 -, Hantu-Hantu Politik dan Matinya Sosial, Tiga Serangkai: Solo, 2003

Publication, 1986

Rakyat Sulsel.Com tanggal 12 Desember 2015. Diakses tanggal 28 September 2017

Rakyatku News, 7 Juni 2017

Ritzer, George, 2010, The Post Modern Sosial Theory, Juxtapose researchand Publication. Sjaf, Sofyan, Politik Etnik: Dinamika Lokal di Kendari, Yayasan Pustaka Obor, Jakarta 2014

Soesilo, Dwi Rachmad, 20 Tokoh Sosiologi Modern, Ar Ruzz Media: Yogyakarta, 2008. Sunaikah, Lailis, Peran Personal Branding Elit Politik dalam Pembentukan Identitas Partai Politik. (Studi deskriptif kualitatif Personal Branding Prabowo dalam Iklan TVC Partai Gerindra), Skripsi; UIN Sunan Kalijaga Yogyakarta, 2014

Wibowo, Ananda Rezky, Perempuan Dan Kepemimpinan Politik; Studi Terhadap Terpilihnya Indah Putri Indriani Sebagai Bupati Di Kabupaten Luwu Utara, Jurusan Ilmu Politik Fakultas Ushuluddin, Filsafat Dan Politik Universitas Islam Negeri Alauddin Makassar 2017

Widyawati Kimbal, Rahel Modal Sosial dan Ekonomi Industri: Sebuah Study Kualitatif, Deepublish: Yogyakarta,2015

http://e-lkp.uin-alauddin.ac.id/index_981.php 